\title{
Index
}

Note: authors' names are listed once only, against the page where they are first mentioned. Archival sources, material in the notes at the end of the chapters, figures and tables are not listed in the index. Abbreviations are defined in the list on page xii.

1907 revolt $9,10,11,13,21-45,79,86$, 194, 196

effects and legacy of $1,9,15,24,36$, $41,43,45,52,53,58-59,90,94$, $107-108,111,128,152,166,169$, $190,216,219,220,230-231,261$, 263,265

ideology and rhetoric of 12,21 , $22,23,28,45,60,61,68-72,79$, $87,100,102-103,105,117,130$, $139,181,189,190,195-196,217$, 225-226, 247-249, 261, 267

myth of $24,45,116,155,251,262$, 266

pre-history of 24-29

regionalism and 11, 36-45, 130-131, 153

1968 protests (in France) 11, 13, 100, 102-109, 118, 120, 140-145, 149, 153,265

legacy and impact of $13,14,106$, $108,134,140,144-145,146,149$, $153,155,157,233$

see also années 68 accusations of fraud 117, 183, 216 see also fraud

Action Directe (AD) 232, 233, 234

agricultural union $91,104,142,179$, 213, 243 see also trade union

Agulhon, M. 19

Albert, M. 10, 12, 22, 23, 28-32, 34, $35,37-39,41,44,51,60,68,74$, $86,87,103,104,106,107,117$, $128,152,178,180,259$

Albigensian crusade 38, 40, 153 see also cathars

Aldy, F. 32, 34

Algerian war effects of 75

Evian Accords 94, 96, 102 significance of 94, 95, 96 support for 76

Algerian wine 31, 94, 96-98, 102, 123, $177,183,261$

Alland, A. 124

Alliès, P. 138, 160

American influence 23, 244, 247, 252 
culture 253, 263

modernisation and 16, 89

see also Mondavi

American retaliation against France 245

American vines 25

années 68 133, 140-142, 144

see also 1968 protests

anti-capitalism

of the CRAV 139

of Huillet 191

of the Occitan Movement 143

anti-globalisation 9, 16, 242-246, 253, 255

see also globalisation and the CRAV

AOC $60,61,110,174,187,207,208$, 209, 210, 211, 227

Ariès, P. 256

arrachage see uprooting

Artichoke Committee 92

Artières, P. 265

Artières, P. and Zancarini-Fournel, M. 20,124

attacks 90, 97, 171, 180, 183, 188-189, 194, 203-204, 229, 231, 254, 265, 267

support by women 101

see also CRAV action; direct action

Audigier, F. 201

Augé, J. 28, 30, 37

austerity measures 185,188

autogestion see worker selfmanagement

Bairner, A. 18

Bardissa, J. 81

Barlangue, L. 51

Barthe, E. 44, 52, 60, 62

Barthes, R. 2, 17

Bartoli, P. 236

Bartoli, P. et al. 82, 125

Basque nationalists 234, 246

Baycroft, T. and Hewitson, M. 18

Bayou, R. 57, 62, 68, 70, 77, 227

Beaud, M. 200

Bechtel, G. 19, 45, 46, 49, 51
Bentegeac plan 164, 165, 174, 178, 213

effects of 168-171

Bérard, L. and Marchenay, P. 18

Berger, S. 18

Bergounioux, A. and Grunberg, G. 200

Berriet, M. et al. 237

Berstein, S. et al. 49, 196

Blanc, L. 22

Blockage (blocage) 63, 65, 66, 250

bombings $15,148,171,180,187,204$, 228, 231, 232, 254

see also CRAV action

Bonnave Plan 66, 77

Bordeaux 4, 6, 90, 169, 170, 208, 211, 250-252

Bosc, P. 116, 127

Bouzdine-Chemeeva, T. and Krzywoszynska, A. 256

Bové, J. 148, 244-255, 256, 261

Bové, J. and Defour, F. 256

Breton activism 89, 91-92, 234

Breton regionalism and the Midi 144

Brittany inspired by the Midi 40

Brown, B. 159

Bruneteau, B. 122

Burgos, A. 19

Calamel, S. and Javel, D. 158

Calas, J. 72

Calas, R. 23

Campbell, J. 24, 46

Camproux, C. 130, 131, 136, 158

Capdevielle, J. and Mouriaux, R. 159

Cases, A. 8, 9, 97, 103, 105, 182, 187, $188,189,227,230$ condoning violence 193 direct action and 90, 97

Castéra, A. 8, 9, 86, 105-106, 228, 266 politics of 128

popularity of $102-103$

support for 106,107

Catalan movement 130

Cathars 38-39, 128, 134, 136, 144 see also Albigensian crusade

Cazals, R. and Fabre, D. 47 
CGVM 35, 41, 42, 45, 59, 67, 69, $180-181$

rejuvenation of 89-90

as symbolic Midi organisation 180 and syndicalism 167

Chanet, J.-F. 19

Charles-Brun, J. 11, 39, 40, 48, 49, 50, 136, 137, 246

Charlton, S. 240

Charmes, F. 49

Chevènement, J. 237

Chiffoleau, Y. 237

Chiffoleau, Y. et al. 256

Chirac, J. 110, 215

confrontations with the CRAV 109 promises to the vignerons 110

Chirac Plan 164-165, 207, 211, 213, 219,222

Clarke, J. 263, 268

class structure in Languedoc 26, 31, 42,52

Clavel, J. 19, 211, 212, 247, 256

Clout, H. D. 46

CMA 60, 61, 67, 225

Code du vin 65, 66, 69, 77, 94

COEA 133, 136, 137, 139, 141, 143-145, 147-149, 158, 159, 160, 161

cultural autonomy and 143

Proudhonism and 143

Cohen, E. 200

Cole, A. and Raymond, G. 160

Comité d'Argeliers 10, 30, 31, 37, 40, 94

Commission des Boissons 62, 68, 122

Common Agricultural Policy 173, $175,186,243$

Confédération Générale des Vignerons du Midi see CGVM

Confédération Paysanne (CP) 179, 243-245

consommation courante $56,60,67$

cooperatives $52,57,58,66,86,181$

and activism 90

autogestion and 190

centrality of 261

decrease in 208 in the Défense movement 60

and FNSEA 205

growth of $28,44,52,55,57$

and modernisation 55

organic wine and 252, 253

politics of $140,165,173$

and production 58, 66

and representation 58

solidarity of 181

and uprooting 61, 209

and the viticultural union sacrée 27,

$30,178,180$

weakening of 209

and workers' organisations 63

cooperativism 143

Corsican activism 119, 203, 234

Corsican nationalists 234

Cosseron, S. 240

Coste-Floret, P. 72, 96, 97

CRAV action against EEC in 1983187,188

commando raids 109, 177, 203, 204, 205

in 1981183

in 1982183,184

in 2005250

reaction to Dublin Accords 213, 214

reasons for the CRAV violence 109, 110

responses to the CRAV violence 151

support of PS programme 176 see also attacks; bombings; direct action; interception of wine tankers; Leclerc store attack; Montredon shootout

CRAV structure and development characteristics of the CRAV 2, 91, 120

condemnation of the CRAV 231, 232

decline in support for the CRAV 15, 206, 242, 252, 254, 255, 260, 261, 262

disunity in the CRAV 226, 227

lack of vision 189, 190, 191 
leadership 152, 222

marginalisation of the CRAV 194, $195,215,225,226$

and the Occitan movement 149, 155

organisation of the CRAV 107, 108, 113

politics of the CRAV 105, 128

rejuvenation of the CRAV 267

resistance to fraud 191, 194, 216, 254,261

support for the CRAV 90, 228

support of women for the CRAV 99

credit and cooperatives 56, 80

Crettiez, X. and Sommier, I. 158

Compagnies Républicaines de Sécurité (CRS) 87, 88, 96, 97, 102, 104, 109, 114, 115, 117-120, $172,193,194,214,266$

\section{CRSV 67}

appeasement of 74

Défense movement and 71

lack of radicalism and 73

origins of CRSV 67, 68, 69

Damamme, D. et al. 85, 124

Dartnell, M. 240

Debatisse, M. 81, 173, 174

Debré, M. 91, 145, 147

Decazeville see miners' strike

decolonisation $8,72,133,136$

Dedieu, O. 12, 20, 51

Défense movement

decline in support for 187, 188, 195

demands of 58,60

developments $44,69,70$

origins of $9,10,31,60,63$

rejuvenation of $71,72,79,97$

resistance to change 216

splintering of 53, 224

vs FNSEA 229

Delale, A. and Ragache, G. 127

demonstrations 78, 231

against Italian wine imports 172

changes from 1949-91 221

in $1953-5463,71,72,73$ in 196187,88

in $1967102,104,105,141$

in 1971150

in $1975111,112,115,116$

in 1981177

in 1988229

in 1989230,231

in 1991231

in 1992232

in 2008267

see also protests

Demossier, M. 6, 18

Derieux, E. and Texier, J. C. 19

De Sède, G. 127

direct action 2, 13-15, 17, 42, 53

$67-73,78,87,90-92,95,98$

101-102, 105, 108, 109, 112-117,

$119,133,138-139,142,155,193$,

195, 221, 233, 261, 264, 266

see also CRAV action

distillation of alcohol 28, 32, 58, 63, $64,65,66,69,72,73,75,111$, $178,182,187,213,249,251$

Don Quixote 22, 35, 183, 184

Dubois, A. 32

Dubos, J. 81

Duclos, N. 122

Dugrand, R. 25, 46

dumping uprooted vines as a symbol 218

see also ritualised protest

economic hardships $11,14,16,28,29$, $33,35,59,67,133,138,139,185$

economic interests 79, 87, 130, 139

economic reform post-war 4

EEC 186, 217

legislation and vin de table 208

opposition to the EEC by the CRAV 171

protests against 187

regulations 15

Ehrmann, H. 81

European Common Market 88, 96, $187,189,213$

European integration 191, 192, 212-213 
European regulation

of wine imports 176, 193

of wine production 106, 209

Farmer, S. 162

fascism 114, 130, 131

Fassin, E. 262

Félibrige 11, 38, 130, 132, 137 see also Occitan culture

Ferroul, E. 12, 27, 31-35, 38-39, $41-45,60,70,71,86,104,108$, $117,128,130,152,178,180$

Fields, B. 240

Fitzgerald, S. 80

FNSEA 70, 173, 174, 179, 184, 215, 216,249

and CGVM 219, 220

and conflict with the CRAV 191

influence of 184, 185

opposition to 77,78

stance on fraud 167

support of $167,182,193$

Fonteneau, A. and Muet, P. 200

Fontvieille, J. R. 46

Ford, C. 19

Frader, L. 47, 50

Franco-Prussian War (1870) 49

fraud 9,32

as cause of Midi problems 94, 97

as reason for downturn 26, 30, 31

demonstration against 232

discouragement of 178

Dreyfus affair and 41

in AOC 60

prosecution of 34

regulation of 176

resistance to 43,189

rhetorical value to the CRAV 217

fraud accusations 32

Italian wine accusations 15, 183

regional identity and 249

French Revolution (1789) 3, 21, 29, $36,37,39,46$

Friend, J. 200

Gadaffi, M. 151

Gallic-Anglo-Saxon conflict 16
Galtier, G. 81

Gavignaud-Fontaine, G. 10, 18, 80

Gélis, Mme 99, 100, 102

Germond, C. S. 245, 256

Gerson, S. 19

Gilbert, Y. 182

Gilbert, Y. and Meistersheim, J. 124

Gilcher-Holtey, I. 162

Gildea, R. 19, 125

Gildea, R. and Tompkins, A. 90, 121

globalisation and the CRAV 195, 242, 249,259

see also anti-globalisation

Gobille, B. 20

Goldey, D. B. 84

Goldey, D. B. and Knapp, A. F. 198

Gordon, D.A. 125, 160

Goury, B. 198

government policy and reform 4,76 , $102,174,184,185,189,191,212$, 213

see also regulation; legislation

Grande, G. 159

grape varieties $2,65,66,110,165,208$, 209-211, 219, 224

grubbing up 64 see also uprooting

Guesde, J. 27, 32, 34, 47

Guesdisme (support for Guesde) $27,44,70,130$

Guillon, J. 159

Gurr, T. 109, 125

Guy, K. 18

Hamon, A. 240

Hanley, D. 201

Hanshew, K. 241

Hébert, L. and Noël, F. 159

Henry, L. and Lagadec, A. 241

Hobsbawm, E. and Ranger, T. 162

Holmes, G. M. and Fawcett, P. D. 80

Holmes, P. 196

Huillet, J. 16, 114, 128, 142, 154-155, 176-177, 183, 189-194, 214, 216, $217,222-227,244,246,249-254$

Hunt, J. 85 
Indochina 72

see also decolonisation

Institut d'Éducation Occitan 130

interception of wine tankers 97,102 , $116,177,180,183,187,192,206$, 231

see also CRAV action

inter-classisme 28, 30, 31, 37, 41, 44, 53,71

internal colonialism $72,117,136,138$, $146,150,155$

Isnard, H. 123

Italian wine imports 110,118

resistance to 216

Jackson, J. 43, 49, 125

Jaurès, J. 27, 32, 34, 37, 39, 42, 47, 48

Jeanneney, J. M. 84

Jones, A. 198

Jones, A. and Clark, J. 18

Jouveau, R. 158

Judge, A. 159

Juge, J. 199

Keeler, J. 198, 199

Kielstra, N. 46

Klajman, N. and Touzard, J.-M. 168, 236

Klein, N. 245

Knox, T. C. 46

Kuisel, R. 20, 121

La Dépêche 8, 39, 87, 115, 171, 231, 259

Lafont, R. 20

landowners 26, 31, 32, 42, 74, 154

Larkin, M. 45

Larzac 105, 129, 136, 145-149, 153, $173,243,245,246$

international character of 143,146 , 147

Lauraire, R. 47

Laurentin, E. 94

Laven, D. and Baycroft, T. 18

Lebovics, H. 19

Le Bris, M. 19, 159, 162
Leclerc store attack (1984) 203-206, 229, 250, 265 see also $\mathrm{CRAV}$ action

legislation $60,61,65$

in 1930s 53

in 194956,57

see also government policy and reform; regulation

Lehning, J. R. 18

Lem, W. 18

Le Pape, Y. et al. 237

Le Pape, Y. and Smith, A. 237

Le Tocsin 22, 30, 31

Ligue des Petits et Moyens Viticulteurs $59,69,70,72,73$

L'Indépendant 8, 10, 100, 115, 227, 235

Loubère, L. 18, 48

Lucand, C. 80

Lukes, S. 127

Lutte Occitane 134, 136-137, 141, 146-148, 153-154

Lynch, E. 50

McDonalds 16, 245, 248, 249, 253, 256

McFalls, L. 19, 237

Machin, H. and Wright, V. 85

McKay, I. 160

Macridis, R. C. 80

Maffre-Baugé, E. 12, 71, 83, 96-97, 109, 129, 141-142, 157, 166, $172-174,178,184-185,189$, 191-192, 214-217, 226

Mallet, S. 132, 159

Mann, P. 127

Mark, V. 20

Martel, P. 39, 49

Marti, C. 149, 153, 162

Martin, D. 124

Martin, J. P. 83, 127, 162, 255

Martin, P. 81, 131, 158

Marx, K. 29, 36 marxism 40, 47, 130, 137, 143, 153, 158,234

Medrano, J. and Gutiérrez, P. 200

Midi Libre 8, 74, 88, 115, 165, 187, $222,226,229,231$ 
miners' strike (at Decazeville pit) 129 , $133,137-139,140,144,146,153$

Mistral, F. 11, 38, 39

Mitterrand, F. 15, 137, 157, 164, 175, $176,179,183,184-186$

and autogestion 190

challenges to the CRAV 195

commitment to agricultural sector 180

end of honeymoon 184

modernising agenda 207, 214, 215, $218,222,224$

support for $15,178,179$

MIVOC 128, 129, 154, 225, 246

MODEF 142

characteristics of $77,78,167,179$

and the Ligue 78

opposition to EEC 213, 214

recognition by government 179

support of Défense movement 218

and syndicalism 167

modernisation $14-15,17,25,62$,

$88-89,120,139,169,170,175$,

$178,186,262$

accenting of 191, 195, 204, 205,

$211,216,221,226,232,248,255$,

263-264

attitudes to $149,154,155,176,181$, 218

cooperatives and 55-56, 86

and the CRAV 168, 170, 177, 190,

194-195, 204, 224, 249, 262

effects of 25-26, 58, 222, 235, 243

obstacles to 182

production patterns and 77,110 ,

165-167, 208, 224, 261

under Mitterrand 175, 188, 214, 215,218

see also regional defence $v s$

development; regional defence $v s$ identity

Mondavi 16, 247

see also American influence

Monnet, J. 54, 80

Monnet Plan 52, 56, 61

Montredon shootout (1976) 10, 14, 164 commemoration and symbolism 170, 193, 216, 249, 259, 266

legacy and impact 120, 155, 157, $169,171,222,260$

see also CRAV action

Moreau-Defarges, P. 237

Moruzzi, J. and Boulaert, E. 241

Muir, R. 18

Muller, P. 81

myth of 1907 see 1907 revolt

Napo, F. 19

nation-building $6,8,23$

neo-corporatism 93, 122, 167, 190

Nicholas, F. 83

Occitan cross 101, 129-130, 134, 136, $138,150,187$

Occitan culture 108, 131, 132, 133, 149

Occitan language $38,133,134,138$, 147, 246

Occitan movement 12, 13, 116, 134, $135,137,139,148,246$

association with vignerons 129

characteristics of 130

colonialism and 72

development of political

Occitanisme 134

militancy 136, 146

rejection of fascism 132

relevance of 144

support for 42, 145

support for the CRAV 152, 254

support for the IRA 145

Occitan revival, and viticultural activists 150

occupation (Second World War) 8, 45,132 ,

see also Vichy government; resistance

occupation of Montpellier Cathedral (1971) 112, 150, 151

Office du vin 166, 172, 178, 181

organic wine 203, 252, 253 
overproduction of wine $8,32,58,65$, $208,212,213,250,251$ see also wine industry

Palazy, A. 27, 28, 30, 42

Pararas, P. 122

Parker, T. 18

patrimony $2,100,143,144,15,148$, $149,153,155,170,235$

see also regional identity

PCF 23, 45, 67, 70, 79, 157

CRAV and 142

direct action, support of 72

presence in the Midi 62

peasants $59,70,91,255$

class struggle 132

identity 242

peasant unions 77

peasant-worker mentality 142 politics of 91, 94, 96, 114

Pech, R. 19, 47, 48, 120

Pech, M. and Pech, R. 46

Peer, R. 20, 160

Phylloxera 24, 47, 55, 259, 261

Pilbeam, P. 46

Pina, C. 240

Pisani Charter 93

Pitte, J. 237

Plack, N. 46, 48

Porhel, V. 20

post-war crises 58

price of wine $25,26,56,57,61,63,75$, $88,110,177,250$

see also wine industry

Pritchard, S. 18

productivism 55,121

and cooperatives 66,86

rejection of 169

viticulture $62,66,261$

professional bodies $58,59,60,69,78$, $180,194,216$

CRAV and 120

FNSEA and 176

women and 100

see also trade union

professional representation 77, 219, 228,265 progress in the Midi 212

protest $4,32,68,70,261$,

against EEC 172, 189

against the Republic 36, 40

overview of protest movements 261

reasons for 104

see also CRAV action; demonstrations

Proudhon, P. 161

Proudhonism 132, 136, 137

PS $70,172,175,176,181,183,185$, 190, 191, 206, 212, 214, 216, 220, $213,218,233,260$

CGVM and 220

CRAV and 260

goals of 176

quality of wine $66,178,210,211,212$, 242

promotion of 187

reform of 167,168

Rabelais, F. 3

radicalisation

of the CRAV 98, 108

of the Défense movement 142

of protest 187

Radicals 29, 30, 34, 36, 40

Ramond, J. 222, 223, 224

Ramsay, R. 241

Ravis-Giordani, G. 241

Rawlinson, R. 159

Raynaud, P. 240

regional defence $v s$ development 205, 218

see also modernisation

regional defence $v$ s identity 170,177

see also modernisation

regional identity $15,23,24,36,38$, $128,136,137,154,211,225$

and conservatism 137

and heritage 11

see also patrimony

regionalism 14, 36, 40, 116, 129

the CRAV and 108, 117

regional autonomy 130,136

see also Occitan movement 
regional media $8,15,115,152,245$, 254

regulation

of AOC 208

of fraud 217

of Italian wine 217

of wine 182, 208, 211

of wine imports 171, 176, 193

of wine market 2, 28, 60, 211

of wine prices 167

of wine production 31,66

see also government policy and reform; legislation

Reid, D. 137, 160

republican heritage of Occitanism 12 see also Occitan movement republican values of Languedoc 14 resistance (Second World War) 1, 24, $44,58,61,131,132,158$

see also occupation

resistance to modernisation in the CRAV 195

see also CRAV structure and development

responsibilisation 164, 165, 167, 169

Revel, B. 10, 116

rift between Socialists and the Midi, effects of 186

see also PS

riot $1,13,29,31,32,33,37,40,58,69$, $98,106,140,195,220,247,267$

see also protest

Rioux, J. 50

ritualised protest 110, 182, 195, 219, 230, 231, 263

Rocard, M. 136, 184, 186, 193, 214

Rochfort, J. 269

Roger, A. 109, 122, 201

Ross, K. 20

Ross, R. and Jenson, J. 200

Rouzier, J. 197

Ruffat, M. 122

Sagnes, J. 19, 47, 48, 81

Sagnes, J. and Séguéla, J. 47

Sagnes, J. et al. 46

Salles, J. 161
Sawicki, F. 238

Secondy, P. 50

Seifert, F. 255

SFIO 27, 28, 32, 33. 34, 37, 38, 41-44, $52,62,63,67,70,77,79,107,173$ see also PS

sheep see Larzac

small-holders

characteristics of 26,31

Communist party and 53

cooperatives and $56,58,60$

the CRAV and $11,86,90,97,109$, 206, 222

decline in 168, 208

economic hardships of 206, 208

modernisation and 52, 62, 176

motivations of 11

representation of $72-74,78,179$, 219

uprooting and 64

vulnerability of 28

wives of 100

Smith, A. 175, 198

Smith, A. et al. 236

Smith, A. W. M. 123

Smith, A. W. M. and Hawkey, J. W. 49

Smith, J. and Moncourt, A. 240

Smith, J. H. 31, 46

Smith, N. 159

Socialist party $15,28,36,37,43,62$, 77

see also PS; SFIO

Sommier, I. 240

Soulié, E. 74, 78, 218

Spain

accession to the EEC 171, 186, 188, $189,212,214$

fraudulent wines 216

Spufford, F. 20

Stevenson, I. 47

Storm, E. 20

Strohl, J. and Tostain, A. 210

subsidies $55,75,89,93,144,154,165$, $166,169,174,175,182,184,188$

symbols of identity $7,23,24,40,45$, $79,105,263$

syndicalist movement see trade union 
table wine $25,56,61,186,187,249$

Tartakowsky, D. 113, 122

Tavernier, Y. 83

taxation 29, 92, 139, 183, 248

tax strike 33

Teisseyre, A. 156, 157

Temple, L. et al. 80

Terral, P. 198

terroir 2, 3, 6, 17

terrorism $10,15,117,204,228$, 232-234, 242, 245, 268

theatre $32,33,134$

Thiesse, A. 158

Tilly, C. 48

Torres, O. 236, 256

Tour de France 254

Touzard, J. and Laporte, J. 210

trade union 204, 229, 231, 243

see also agricultural union

Trubek, A. 18

under-development in the Midi 120

uprooting $61,63,64,164,170,178$, $197,213,218$

alternatives to 65

consequences of 205

effects of 169, 208, 209

effects on the Défense movement 170

Vals, F. 107

Varon, J. 240

Vercherand, J. 81

veterans 94-96

see also Algerian war

Via Campesina 244

Vialade, J. 108

Vichy government $8,24,44,45,53,60$, $61,130,158$

Vidal, R. 67, 68, 70

Vigna, X. 20, 161

vignerons $6,30,37,108,129$

activism of $87,97,171$

aligned with Breton revolt 40

conflict with government and 16, 30

conflict with the CRS 88, 108, 117 cooperatives and 27

demands of 104

economic hardships of 37

expectations of Chirac 110

marginalisation of 108

modernisation and 149

occupational identity of 26, 116

opposition to EEC 172, 187, 188, 194

opposition to uprooting 93

popular support of 90

relevance of 1968 to 106

sympathy for 129

see also Défense movement;

winegrowers' movement

vin de pays 110, 211

Vinen, R. 50

violence 192

in 1950 s 76

in 1960 s $87-88,102,104$

in 1970s $109,117-120,151,171$

in 1980 s $180,186,192,194-195$, 203, 205, 229

in 1990s $228,231,232$

in 2000s 250, 254, 265

symbolic acts of vandalism in

Carcassonne 229

symbolic destruction of McDonalds 245

unacceptability of 112

see also CRAV action

violence in Corsica 119

viticultural radicals 68, 90, 214

see also Défense movement

viticultural unity $9,181,182,188,191$, $194,204,225,229,232$

ideals of 59,168

Wall, I. M. 80

Wardhaugh, J. 49

Warner, C. K. 47

Waters, S. 244, 256

Weber, E. 6, 18

Weber, H. 134, 159

Whitfield, L. 75, 84

Williams, G. 256

Williams, P. 50 
wine cooperatives 27 see also cooperatives

wine crises 14, 29, 31, 53, 63, 6675 , 251

winegrowers' movement $8,12,14$ see also Défense movement; vignerons

wine industry $3,4,8,11,12,14,15$, $52,56,182,242$

changes in production patterns 206-212

decline in wine consumption 63,66 , $74,86,177,178,206,207,208,261$ decline of winegrowing 235 reforms $24,25,28,32,52,58$ wine scandal (1986) 208, 217

women

marginalisation of 99 role in 1907 protest 98 role in 1970 protest 102 symbolic positions of 79, 101

worker self-management 176, 178, 189,190

Wright, G. 122

Wright, J. 20

Zancarini-Fournel, M. 10, 19, 20, 162

Zaretsky, R. 19 